Ks. Bogdan CZYŻEWSKI

(Poznań, WT UAM)

\title{
SENS ŻYCIA W OCENIE OJCÓW APOSTOLSKICH
}

Pytanie o sens, a w konsekwencji także o cel życia, towarzyszyło ludzkości od zawsze. Człowiek, należący do gatunku homo sapiens, słusznie zastanawiał się, po co żyje i ku czemu zmierza. Odpowiedzi szły w różnym kierunku, od całkowitego negowania i stwierdzenia, że nic nie ma sensu, aż po przesadną afirmację, zwłaszcza tego, co doczesne i realizowania zgubnej maksymy: jedz, pij i używaj.

Kwestia dotycząca sensu życia musiała także pojawić się u chrześcijan, w szczególności u tych pierwszych i jednocześnie najstarszych przedstawicieli okresu patrystycznego, czyli u Ojców Apostolskich. Powodów do zastanawiania się nad sensem życia było zapewne kilka. Jednym z nich mógł być chociażby okres, w jakim przyszło im żyć. Byli przecież tak blisko czasów apostolskich, w których dominowało przekonanie, że Chrystus już wkrótce powtórnie przyjdzie na ziemię i dokona sądu nad tym światem. Innym powodem, by zająć głos w kwestii sensu życia, mogły być prześladowania, w obliczu których znaleźli się wyznawcy Chrystusa. Należy także brać pod uwage spisane już księgi Nowego Testamentu, w których nader często pojawiał się element Królestwa Bożego jako celu, ku któremu zmierzają chrześcijanie.

W pismach Ojców Apostolskich zauważyć można z jednej strony obcość i zachowywanie dystansu wobec świata doczesnego, $z$ drugiej natomiast świadomość wybrania przez Boga. Świat doczesny to „ten eon”, życie wieczne zaś to „eon przyszły”. Tego rodzaju rozróżnienie przejęli od Żydów ${ }^{1}$. Dlatego też chcemy w tym artykule postawić pytanie o poglądy Ojców Apostolskich na życie, zwłaszcza ziemskie. Czy stanowiło ono dla nich jakąkolwiek wartość? A może liczyło się dla nich tylko życie wieczne? Jak pogodzić wpisane w serce człowieka naturalne pragnienie życia na ziemi, skoro niektórzy pragnęli męczeństwa? Z drugiej zaś strony, co mówili Ojcowie Apostolscy na temat życia wiecznego ${ }^{2}$ ?

${ }^{1}$ Por. W. Myszor, Kierunki rozwoju chrześcijaństwa $w$ okresie poapostolskim (wstęp), w: Ojcowie Apostolscy, tłum. A. Świderkówna, PSP 45, Warszawa 1990, 15.

${ }^{2}$ Polecam także na ten temat: Człowiek w perspektywie doczesności i wieczności. Antropocentryzm Ojców Kościoła, red. B. Częsz, Poznań 2006 (= TPatr 3). 
1. Motyw dwóch dróg. Zagadnienie sensu życia pojawia się w pismach Ojców Apostolskich najpierw w formie ciekawego tematu związanego z motywem „dwóch dróg”. Nie jest on nowy i wymyślony przez Ojców, znany był już bowiem w żydowskiej katechezie opartej na Deuteronomium oraz w qumrańskiej Regule Zrzeszenia ${ }^{3}$. Cztery pisma Ojców Apostolskich podejmują temat „dwóch dróg”, a mianowicie: Didache, List Barnaby, Pasterz Hermasa oraz List do Kościoła w Magnezji św. Ignacego Antiocheńskiego. Już sama nazwa - dwie drogi - wskazuje na dwie możliwości, jakie ma do wyboru człowiek.

Autor Didache mówiąc o dwóch drogach nazywa jedną z nich drogą życia, drugą zaś drogą śmierci. Tym samym przekonuje, że kroczenie pierwszą $\mathrm{z}$ nich daje nie tylko nadzieję przyszłego życia, ale prowadzi też człowieka do wieczności. Taki też jest sens przestrzegania Bożych przykazań i unikania wszelkich grzechów. Autor Didache bardzo szczegółowo wylicza dobrze nam znane nakazy i zakazy, których źródło odnaleźć można w Piśmie Świętym. Jedne mają wyraźnie negatywny oddźwięk, jak np. niektóre przykazania i normy moralne:

„nie zabijaj, nie cudzołóż, nie uwodź młodych chłopców, nie uprawiaj rozpusty [...] nie zajmuj się magią i czarami”",

drugie stanowią wyraźny nakaz:

„powstrzymuj się od umysłowych i cielesnych pożądań, daj każdemu, kto cię prosi"s,

jeszcze inne natomiast posiadają charakter zachęty:

„Dziecko moje, stroń od wszystkiego, co złe [...] kto głosi ci słowo Boże, pamiętaj dniem i nocą".

Droga śmierci jest całkowitym zaprzeczeniem drogi życia, ponieważ opanowana jest przez zło i przekleństwa. Tutaj autor Didache wylicza cały katalog tego wszystkiego, co prowadzi do zguby. Nie ma już nakazów, zakazów i zachęt, ale konkretne grzechy związane $\mathrm{z}$ taką właśnie formą postępowania: mordy, cudzołóstwa, pożądania, rozpusty, ci natomiast, którzy obierają

\footnotetext{
${ }^{3} \mathrm{Na}$ temat odkryć w Qumran oraz samej Reguły Zrzeszenia powstało wiele monografii, warto tu wspomnieć m.in. następujące opracowania: W. Tyloch, Rękopisy znad Morza Martwego po dwudziestu latach, „Euhemer” 12 (1968) nr 2(68), 21-38; Z.J. Kapera, Aktualny stan badań nad rękopisami z Qumran, „Euhemer” 2/4 (1989) 33-57; J. Fitzmyer, 101 pytań o Qumran, thum. T. Fizia, Kraków 1997; P.R. Muchowski, Rękopisy znad Morza Martwego. Qumran-Wadi Murabba'atMasada-Nahal Chewer, Biblioteka Zwojów 5, Kraków 2000; A. Tronina, Formalne cytaty biblijne w ,, Regule Zrzeszenia” z Qumran (1QS), RT 48 (2001) z. 1, 53-61.

${ }^{4}$ Didache 2, 1, SCh 248, 148, thum. A. Świderkówna, PSP 45, Warszawa 1990, 57.

${ }^{5}$ Tamże 1, 4 i 5, SCh 248, 144, PSP 45, 56-57.

${ }^{6}$ Tamże 3, 1 i 4, 1, SCh 248, 152 i 156, PSP 45, 58.
} 
drogę śmierci to prześladowcy ludzi prawych, wrogowie prawdy, miłośnicy kłamstwa ${ }^{7}$.

Barnaba zaś w swoim Liście nie mówi już o drodze życia i śmierci, ale o drodze światła i ciemności, ponieważ odpowiadają one dwom rodzajom nauk. Autor tłumaczy nawet użycie takiej właśnie nazwy:

„Na jedną straż trzymają wiodący ku światłości aniołowie Boży, nad drugą - aniołowie Szatana. Bóg jest Panem od wieków i na wieki, Szatan zaś księciem czasów obecnych, czasów niegodziwości"».

Kroczyć drogą światła oznacza, podobnie jak pouczał autor Didache, przestrzegać przykazań Bożych i kierować się w życiu prawem miłości, zarówno do Pana Boga jak i do drugiego człowieka. Odnajdujemy tutaj cały szereg konkretnych wskazań, co należy czynić, a czego unikać. Droga ciemności nazwana została także drogą Czarnego (w dwóch miejscach swojego Listu Barnaba używa takiego określenia na Szatana $)^{9}$, jest ona kręta, pełna przekleństwa, jest drogą śmierci wiecznej i kary ${ }^{10}$. Autor Listu mówi wyraźnie o nagrodzie bądź też karze, w związku z kroczeniem konkretną drogą. Jeżeli ktoś postępuje zgodnie ze wskazaniami zawartymi w Piśmie Świętym, uważanym za objawienie woli Pana, to:

„dostapi chwały w królestwie Bożym, kto zaś wybierze drogę drugą, ten zginie razem ze swymi dziełami. Dlatego właśnie jest zmartwychwstanie, dlatego jest zapłata za wszystko" 1 .

Temat dwóch dróg podejmuje także autor Pasterza - Hermas. Nie mówi jednak wprost o drogach, ale o podwójnym działaniu: tego, co sprawiedliwe i tego, co niesprawiedliwe ${ }^{12}$. Postępowanie zgodne ze sprawiedliwością związane jest $\mathrm{z}$ chodzeniem drogą prostą i równą. Postępowanie zaś niesprawiedliwe to kroczenie drogą kręta, nieprzetartą, trudną do przebycia, pełną przeszkód, kamienistą i zarosłą cierniami. Pierwsza prowadzi do Boga, druga natomiast do zguby ${ }^{13}$. Motyw dwóch dróg w Pasterzu Hermasa odnosi się także do dwóch aniołów: sprawiedliwości, który:

,jest delikatny, skromny, cichy, spokojny. Kiedy on przyjdzie do twego serca, zaraz zaczyna mówić z tobą o tym, co sprawiedliwe, czyste i święte, o umiarkowaniu, o wszelkich czynach sprawiedliwych i chwalebnych cnotach" ${ }^{\prime 14}$.

\footnotetext{
${ }^{7}$ Por. tamże 5, 1-2, SCh 248, 166-168, PSP 45, 59-60.

${ }^{8}$ Epistula Barnabae 18, 1-2, SCh 172, 197, tłum. A. Świderkówna, PSP 45, 131.

${ }^{9}$ Por. tamże 4,10 i $20,1$.

${ }^{10}$ Por. tamże 20, 1, SCh 172, 211, PSP 45, 133.

${ }^{11}$ Tamże 21, 1, SCh 172, 214, PSP 45, 133.

${ }^{12}$ Por. Hermas, Pastor Mand. VI 1, 2, SCh 53bis, 170, tłum. A. Świderkówna, PSP 45, 160.

${ }^{13}$ Por. tamże Mand. VI 1, 2-5, SCh 53bis, 170, PSP 45, 160.

${ }^{14}$ Tamże Mand. VI 2, 3, SCh 53bis, 172, PSP 45, 160.
} 
Inny jest natomiast anioł zła:

„skłonny do gniewu, złośliwy i bezrozumny, a czyny jego złe i przynoszące upadek sługom Bożym"15.

Hermas poleca, by postępować w życiu za aniołem sprawiedliwości, wyrzec się natomiast należy anioła zła.

Motyw dwóch dróg podejmuje także św. Ignacy Antiocheński; czyni to jednak bardzo ogólnie. W Liście do Kościoła w Magnezji stwierdza:

„wszystko ma swój koniec i dwie rzeczy przed nami jednakowe do wyboru: życie i śmierć, a każdy musi iść swoją drogą. Podobnie dwie są monety, moneta Boga i moneta świata, a każda z nich ma znak własny, niewierni mają na sobie znak tego świata, wierni zaś w miłości - znak Boga Ojca przez Jezusa Chrystusa. Jeśli nie wybieramy przez Niego dobrowolnie śmierci, aby mieć udział w Jego męce, nie ma w nas Jego życia"16.

Prawdziwy sens życia można zatem, według Ojców Apostolskich, osiągnąć na drodze życia, światłości, sprawiedliwości, słuchając podszeptów dobrego anioła. Postępując taką właśnie drogą odnajdzie człowiek życie wieczne i Boga, ku któremu na ziemi pielgrzymuje. Motyw dwóch dróg posłużył zatem Ojcom Apostolskim do ukazania sensu postępowania w życiu doczesnym, zgodnego z przykazaniami Bożymi i wolą Bożą. Można zatem stwierdzić, że świat doczesny pomaga osiągnąć życie wieczne, tutaj bowiem realizuje się przyszłość człowieka, na drodze życia. Nie ma więc u Ojców Apostolskich potępienia świata doczesnego. Potępiona została natomiast droga śmierci, postępowanie nią prowadzi bowiem do zguby, staje się bezsensowne, a jej przedłużeniem jest życie pośród potępionych. Negatywnie ocenione zostały wszelkie złe uczynki, które towarzyszą drodze śmierci, ciemności i niesprawiedliwości.

2. Sens życia doczesnego. Na temat sensu życia Ojcowie Apostolscy wypowiadali się także w kontekście życia doczesnego. Czy oceniają je negatywnie i dostrzegają w nim, jak starożytny mędrzec Kohelet, wyłącznie „marność nad marnościami”? (Koh 1, 2). Jaki cel posiada życie ziemskie? Czy wolno mówić o jakiejkolwiek wartości życia doczesnego?

Klemens Rzymski w swoim Liście do Koryntian chwali tych, „którzy pragną pobożnie i sprawiedliwie prowadzić życie święte"17. Celem zaś jego pisma, jak zaznacza w ostatnich zaleceniach, było przypomnienie Koryntianom, aby podobali się „Bogu Wszechmogącemu przez życie święte

\footnotetext{
${ }^{15}$ Tamże Mand. VI 2, 4, SCh 53bis, 172, PSP 45, 160.

${ }^{16}$ Ignatius Antiochenus, Epistula ad Magnesios 5, 1, SCh 10, 82, tłum. A. Świderkówna, PSP 45,74 .

${ }^{17}$ Clemens Romanus, Epistula ad Corinthios 62, 1, SCh 167, 200, tłum. A. Świderkówna, PSP 45,54 .
} 
w sprawiedliwości, prawdzie i wytrwaniu"18. Wspomina także mężów „pewnych i mądrych, których życie wśród nas od młodości aż do późnego wieku było bez zarzutu"19.

Ignacy Antiocheński, który może uchodzić za negującego wartość życia ziemskiego, chociażby $\mathrm{z}$ tego powodu, że tak bardzo pragnął męczeństwa i nie przywiązywał wagi do swojego ziemskiego bytowania, zaskakuje swoimi poglądami dotyczącymi sensu życia na ziemi. Dostrzega jego wartość, można bowiem - zdaniem Ignacego - żyć według Boga, jeżeli ludzi nie dzielą żadne niepotrzebne spory. Za św. Pawłem (por. Rz 5; 1Kor 2, 14) zachęca też biskup Antiochii w Liście do Kościoła w Efezie, aby żyć nie według ciała, lecz ducha, ponieważ wtedy człowiek będzie prowadził życie duchowe, gdyż wszystkie jego działania zostaną przeniknięte duchowymi czynami ${ }^{20}$.

Biskup Antiochii dostrzega także konkretny sens życia na ziemi. Jest ono po to, aby prowadziło człowieka do wieczności. W kontekście zaś męczeństwa nie tylko swojego, uświadamia Efezjanom, że przez ich „,miasto wiedzie droga tych, którzy są prowadzeni na śmierć, aby znaleźć w niej Boga"21.

Godna podkreślenia u św. Ignacego jest także jego wypowiedź dotycząca Eucharystii. W Liście do Kościoła w Efezie mówi o ponadczasowym sensie przyjmowania Ciała Chrystusa w życiu doczesnym i chwali chrześcijan, że gromadzą się w jednej wierze „łamiąc jeden chleb, który jest pokarmem nieśmiertelności, lekarstwem pozwalającym nam nie umierać, lecz żyć wiecznie w Jezusie Chrystusie"22. Warto w tym miejscu przypomnieć nieco późniejszy głos na ten sam temat, św. Ireneusza z Lyonu, który może stanowić uzupełnienie i wyjaśnienie tego, co wcześniej napisał św. Ignacy. Biskup Lyonu zaświadcza, że „nasze ciała, które otrzymują Eucharystię, nie są już dalej zniszczalne, ale mają nadzieję zmartwychwstania na wieki”’33.

U św. Polikarpa w Liście do Filipian odnaleźć można jedną wyraźną wypowiedź na temat sensu życia doczesnego. Kiedy mówi o męczennikach stwierdza:

„Oni wszyscy nie biegli na próżno, lecz istotnie w wierze i w miłości, i że są teraz na należnym im miejscu przy Panu, gdyż z Nim także razem cierpieli. Umiłowali bowiem nie świat doczesny, ale Tego, który za nas umarł i którego dla nas Bóg z martwych wskrzesił”24.

Biskup Smyrny zauważa z jednej strony wartość i sens życia ziemskiego, chociażby $\mathrm{w}$ tym, że postępowanie zgodne $\mathrm{z}$ wiarą i miłością oraz cier-

\footnotetext{
${ }_{18}$ Tamże 62, 2, SCh 167, 200, PSP 45, 54.

19 Tamże 63, 3, SCh 167, 200, PSP 45, 54.

${ }^{20}$ Por. Ignatius Antiochenus, Epistula ad Ephesios 8, 1-2, SCh 10, 64, PSP 45, 69.

${ }^{21}$ Tamże 12, 1, SCh 10, 68, PSP 45, 70.

22 Tamże 20, 1, SCh 10, 76, PSP 45, 72.

${ }^{23}$ Irenaeus, Adversus haereses IV 18, 5, SCh 100/2, 612, thum. własne.

${ }^{24}$ Polycarpus, Epistula ad Philphenses 9, 1, SCh 10, 189, tłum. A. Świderkówna, PSP 45, 100.
} 
pienie prowadzi do życia wiecznego, z drugiej zaś przestrzega przed przywiązaniem się do świata doczesnego, który kiedyś należy opuścić.

Barnaba w swoim Liście wymienia trzy nauki Pana. Jedną z nich jest „nadzieja życia”, którą określa jako początek i kres naszej wiary ${ }^{25}$. Wspomniany zatem Ojciec Apostolski wskazuje na cel życia ziemskiego. W innym zaś miejscu zaznacza, że nie można zaprzepaścić męki i cierpienia Chrystusa:

„Otóż jeśli Syn Boży, choć jest Panem i będzie sądził żywych i umarłych; cierpiał, aby jego rany przyniosły nam życie, wierzmy zatem, że Syn Boży nie mógł cierpieć z innego powodu niż dla nas" ${ }^{26}$.

W tej wypowiedzi można także odnaleźć sens i cel życia doczesnego człowieka, powinien mianowicie docenić tutaj na ziemi to, co Chrystus dla niego uczynił przez swoje ziemskie życie.

Sens życia doczesnego ukazany został także przez Ojców Apostolskich w pochwale dzieła stworzenia. Hermas wspomina, że kiedy szedł do Cumae sławił „wielkość, piękno i moc wszystkiego, co Bóg stworzył”27. W innym zaś miejscu jest pełen podziwu dla Boga, który świat stworzył dla człowieka, jemu też poddał całe stworzenie i powierzył mu nieograniczoną władzę nad tym, co stworzy ${ }^{28}$.

Wrażenie negatywnej oceny tego świata mogą sprawiać liczne wypowiedzi wspomnianego wyżej autora Pasterza. Stosunkowo często używa on terminu: „świat doczesny”, „ten świat”. Kiedy anioł wyjaśnia Hermasowi znaczenie czterech barw, jakie potwór miał na głowie z czwartego widzenia, stwierdza, że czarny kolor to świat doczesny, biały zaś to ,świat przyszły, w którym zamieszkują wybrani Boga"29. Dokładna jednak lektura tego rozwlekłego i trudnego niekiedy do zrozumienia utworu dostarcza całkowicie innego spojrzenia na sens życia. Hermas pisze bowiem w swym piśmie:

„Którzy mają niegodziwe zamysły w sercu, ściągają na siebie tylko śmierć i niewolę, a zwłaszcza ci, którzy chcą jak najwięcej na tym świecie posiąść, chełpią się wyniośle swoim bogactwem i nie dążą bynajmniej do dóbr przyszłych" ${ }^{30}$.

Autor nie poddaje zatem krytyce świat doczesny, ale dążenie człowieka do gromadzenia $\mathrm{w}$ tym życiu dóbr ziemskich. To bogactwa tego świata przeszkadzają stać się człowiekowi przydatnym dla Pana. Anioł powiedział do Hermasa:

\footnotetext{
${ }^{25}$ Epistula Barnabae 1, 6, SCh 172, 76, PSP 45, 112.

${ }^{26}$ Tamże 7, 1, SCh 172, 128, PSP 45, 120.

${ }^{27}$ Hermas, Pastor Vis. I 1, 3, SCh 53bis, 77, PSP 45, 135.

${ }^{28}$ Por. tamże Mand. XII 4, 2, SCh 53bis, 204, PSP 45, 169-170.

${ }^{29}$ Tamże Vis. IV 3, 2 i 5, SCh 53bis, 138, PSP 45, 151-152.

${ }^{30}$ Tamże Vis. I 1, 8, SCh 53bis, 80, PSP 45, 136.
} 
„Kiedy byłeś bogaty, nie nadawałeś się do niczego, teraz zaś jesteś przydatny

i zdolny służyć życiu. Starajcie się być przydatni dla Boga!"31.

Autor Pasterza za prawdziwą ojczyznę człowieka uznaje niebo. Życie ziemskie jest tylko przejściowe, które nazywa obczyzną, dlatego też nie poleca gromadzić dóbr tego świata. Nie oznacza to jednak potępienia życia doczesnego, jest to raczej tylko przypomnienie, aby nie traktować życia ziemskiego jako ostatecznego celu człowieka ${ }^{32}$.

Podsumowując wypowiedzi Ojców Apostolskich na temat życia doczesnego należy stwierdzić, że w żaden sposób nie negowali jego sensu i wartości. Nawet w obliczu swojego bliskiego męczeństwa dostrzegali wyraźny jego cel: życie ziemskie jest potrzebne, prowadzi bowiem człowieka do Boga; dzięki niemu odnajduje on Boga. Musi jednak spełnić podstawowy warunek, a mianowicie jego postępowanie zawsze powinno być zgodne z wyznawaną wiarą i przeżywane w miłości. Człowiek na ziemi winien prowadzić życie duchowe i tylko takie posiada swój sens i cel, ponieważ wiedzie go do szczęśliwej wieczności.

3. Nadzieja życia wiecznego. Trzeci jakby temat, który wyczytać można z pism Ojców Apostolskich, dotyczący sensu życia, związany jest oczywiście z życiem wiecznym. Św. Ignacy Antiocheński w Liście do Kościoła w Efezie mówi o nim jako o pełni życia. Wiara zaś jest początkiem tego życia, miłość zaś jego pełnią⒊ Biskup dostrzega także ogromne znaczenie ofiary Chrystusa na drzewie krzyża. Jest ona dla ludzkości zbawieniem i życiem wiecznym ${ }^{34}$. Natomiast w Liście do Kościoła w Magnezji Ignacy uświadamia swoim czytelnikom, że zmartwychwstanie Chrystusa zmieniło całkowicie świat. Przez śmierć Chrystusa „także i nasze życie wzeszło jak słońce" 35 . O zmartwychwstaniu biskup Antiochii mówi także w Liście do Kościoła $w$ Tralleis, że kto wierzy w śmierć Chrystusa, unika śmierci ${ }^{36}$. W innym zaś miejscu w tym samym liście pociesza wiernych:

„Ojciec również na Jego podobieństwo i nas wierzących w Niego wskrzesi

w Jezusie Chrystusie, poza którym nie ma dla nas prawdziwego życia" ${ }^{37}$.

Autor Pasterza natomiast nawołuje do przestrzegania przepisów moralnych oraz do czynienia pokuty. Chociaż w życiu ziemskim sprawiedliwi

${ }^{31}$ Tamże Vis. III 6, 7, SCh 53bis, 116, PSP 45, 145.

${ }^{32}$ Por. tamże Sim. I 1-11, SCh 53bis, 210-211, PSP 45, 171-172.

${ }^{33}$ Por. Ignatius Antiochenus, Epistula ad Ephesios 14, 1, SCh 10, 71, PSP 45, 71.

${ }^{34}$ Por. tamże 18, 1, SCh 10, 73, PSP 45, 72.

${ }^{35}$ Ignatius Antiochenus, Epistula ad Magnesios 9, 1, SCh 10, 88, PSP 45, 75.

${ }^{36}$ Ignatius Antiochenus, Epistula ad Trallianos 2, 1, SCh 10, 96, tłum. A. Świderkówna, PSP 45,77 .

${ }^{37}$ Tamże 9, 1, SCh 10, 100, PSP 45, 79. 
mieszkają obok grzeszników i trudno jest odróżnić jednych od drugich, to jednak w wieczności okaże się, kto zasłużył na nagrodę wieczną ${ }^{38}$. Dlatego anioł zachęca Hermasa:

„Żyj w sprawiedliwości i cnocie, w prawdzie i bojaźni Pańskiej, w wierze, w łagodności, i we wszystkim, co dobre a temu podobne. Tak postępując staniesz się miłym Bogu sługą i będziesz żył dla Niego. I każdy kto by służył dobremu pożądaniu, będzie żył dla Boga" ${ }^{\prime 39}$.

Życie dla Boga stanowi jakby myśl przewodnią Przykazań, które otrzymał Hermas od anioła.

Szerzej na temat życia wiecznego, konkretnie zaś zmartwychwstania, naucza św. Klemens Rzymski w powszechnie znanych trzech obrazach zaczerpniętych ze zjawisk zachodzących w kosmosie i przyrodzie oraz w mitycznym opowiadaniu o ptaku feniksie. Przyszłe zmartwychwstanie zostaje najpierw porównane do zmian, jakie mają miejsce w porach dnia:

„Dzień i noc objawiają nam zmartwychwstanie: noc umiera, dzień wstaje; dzień odchodzi, noc się zbliża" ${ }^{\prime 40}$.

Drugi obraz związany jest z prawem natury dotyczącym ziarna wsianego w ziemię:

„Popatrzmy i na owoce pól: jak odbywają się zasiewy i w jaki sposób wzrastają? Wychodzi siewca i wrzuca w ziemię wszystkie ziarna. One wpadają w ziemię suche i gołe, a tam ulegają rozkładowi. Później z tego rozkładu wskrzesza je wspaniała Opatrzność Pana, tak że jedno ziarno mnoży się wielokrotnie i przynosi obfite plony" ${ }^{41}$.

Trzeci wreszcie obraz zaczerpnął św. Klemens Rzymski z mitycznego opowiadania o ptaku feniksie odradzającym się z popiołów ${ }^{42}$. Całość zaś swoich rozważań na temat przyszłego zmartwychwstania kończy autor Listu do Koryntian pytaniem pełnym nadziei:

„Czyż zatem uznamy to za rzecz dziwną i nadzwyczajną, jeśli Stwórca wszechświata wskrzesi z martwych tych, co Mu służyli, święci, w ufności wiary doskonałej, skoro nawet przez ptaka objawia wspaniałość tego, co nam obiecal?"43

Z przedstawionych wypowiedzi wynika, że nauka Ojców Apostols-

${ }^{38}$ Por. Hermas, Pastor Sim. III 1-3 i Sim. IV 1-8, SCh 53bis, 218-220 i 220-222, PSP 45, 174-175.

${ }^{39}$ Tamże Mand. XII 3, 1, SCh 53bis, 202, PSP 45, 169.

${ }^{40}$ Clemens Romanus, Epistula ad Corinthios 24, 3, SCh 167, 142, PSP 45, 36.

${ }^{41}$ Tamże 24, 4-5, SCh 167, 142, PSP 45, 36.

${ }^{42}$ Por. tamże 25, 1-5, SCh 167, 142-143, PSP 45, 36.

${ }^{43}$ Tamże 26, 1, SCh 167, 144, PSP 45, 36. 
kich dotycząca życia wiecznego związana jest przede wszystkim z przekazaniem nadziei o zmartwychwstaniu, które nastąpi po śmierci. Autorzy nie zajmują się tym, jak będzie to przyszłe życie wyglądało. Ono jest nagrodą za przestrzeganie przykazań, za wybór i postępowanie drogą życia, światłości i sprawiedliwości, za wiarę i miłość, którą człowiek żył na ziemi. Najważniejsze dla nich wydaje się spotkanie z Bogiem w wieczności. W tym też zawiera się sens życia doczesnego, które prowadzi człowieka do zmartwychwstania.

$\mathrm{Na}$ koniec należy stwierdzić, że zagadnienie związane z sensem życia pojawia się w pismach Ojców Apostolskich nie jako temat wiodący, ale też nie okazjonalnie. Różne kwestie, które podejmują wspomniani autorzy, dają im możliwość dotknięcia i rozwinięcia tak ważnego wątku, jakim jest podejście chrześcijanina do życia ziemskiego i wiecznego. W takiej bowiem perspektywie sens życia jest przez Ojców Apostolskich rozpatrywany. Nie można zarzucić im pomniejszania, czy nawet negowania życia doczesnego. Przeciwnie, dostrzegają jego sens i wartość, zwłaszcza wtedy, gdy jest właściwie przeżywane, to znaczy zgodnie ze wskazaniami zawartymi w Piśmie Świętym. Sens życia w ocenie Ojców Apostolskich można streścić w jednym, jakże pięknym zdaniu, autorstwa Sługi Bożego ks. Bogdana Jańskiego, założyciela Zmartwychwstańców, który powiedział: „Żyjmy tak, żebyśmy się w życiu wiecznym nie wstydzili" ${ }^{44}$. Jestem przekonany, że tego rodzaju rozumienie sensu życia mieli na myśli nie tylko Ojcowie Apostolscy, ale także inni święci w całej historii chrześcijaństwa.

\section{THE MEANING OF LIFE IN THE ASSESSMENT OF THE APOSTOLIC FATHERS}

\section{(Summary)}

The issue connected with sense of life appears in the works of the Apostolic Fathers not only as a main subject, but also not occasionally. They used the motif of two roads to show the sense of behavior on the earth, according to the God's commandments and his will. They do not condemn the earthly world but deeds, which lead people to death. Even in the face of his close martyrdom, they saw a clear aim: life on the earth is important, because it leads to God. The Apostolic Fathers tell also the truth connected with eternal life and hope to be used from the dead, which will take place after death. The sense of our life is - it leads a man to the resurrection.

\footnotetext{
${ }^{44}$ B. Jański, Dziennik 1830-1839, Rzym 2001, 436.
} 
